\title{
Synthesis, Crystal Structure and Antimicrobial Activity of a Linear Trinuclear Nickel(II) Complex with Schiff Base Ligand
}

\author{
Cui-Lin Zhang, ${ }^{1}$ Xiao-Yang Qiu, ${ }^{1,2, \star}$ Shu-Juan Liu ${ }^{1}$ \\ ${ }^{1}$ College of Science \& Technology, Ningbo University, Ningbo, 315212, P. R. China \\ ${ }^{2}$ State Key Laboratory of Structural Chemistry, Fujian Institute of Research on the Structure of Matter, \\ Chinese Academy of Sciences, Fuzhou, Fujian 350002, P. R. China \\ *Corresponding author: E-mail: xiaoyang_qiu@126.com
}

Received: 02-03-2019

\begin{abstract}
A new linear trinuclear Schiff base nickel(II) complex, $\left[\mathrm{Ni}\left\{\mathrm{NiL}\left(\mu_{2}-\eta^{1}: \eta^{1}-\mathrm{OAc}\right)\left(\mathrm{OH}_{2}\right)\right\}_{2}\right] \cdot \mathrm{H}_{2} \mathrm{O}$, where $\mathrm{L}$ is the dianionic form of $N, N$ '-bis(5-chloro-2-hydroxybenzylidene)-1,3-propanediamine $\left(\mathrm{H}_{2} \mathrm{~L}\right)$, was synthesized and characterized by elemental analyses, IR spectroscopy, and X-ray single-crystal determination. There are three bridges across the Ni-Ni atom pairs, involving two phenolate $\mathrm{O}$ atoms of a Schiff base ligand, and an $\mathrm{O}-\mathrm{C}-\mathrm{O}$ moiety of a $\mu_{2}-\eta^{1}: \eta^{1}$-OAc group. The Ni atoms have octahedral coordination. The acetate bridges linking the central and terminal nickel atoms are mutually trans.

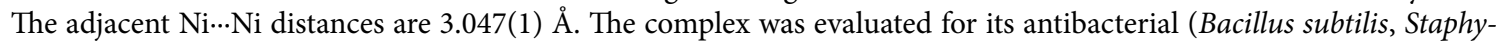
lococcus aureus, Escherichia coli, and Pseudomonas aeruginosa) and antifungal (Candida albicans and Aspergillus niger) activities by MTT (3-(4,5-dimethylthiazol-2-yl)-2,5-diphenyltetrazolium bromide) method.
\end{abstract}

Keywords: Nickel(II) complex; Trinuclear complex; Schiff base; Crystal structure; Antibacterial activity

\section{Introduction}

Schiff bases are biological active compounds bearing the $-\mathrm{N}=\mathrm{CH}-$ functional groups, which can be prepared by the condensation reactions of carbonyl-containing compounds with primary amines. The compounds have been attracted considerable attention for their wide range of biological activities, such as antibacterial, ${ }^{1}$ antifungal, ${ }^{2}$ antitumor, ${ }^{3}$ anti-inflammatory, ${ }^{4}$ and cytotoxic. ${ }^{5}$ Metal-organic complexes containing Schiff bases and bridging ligands are of current interest because of their interesting molecular topologies as well as the fact that they may be designed with specific functionalities. ${ }^{6}$ Among the bridging groups, acetate anion is highly flexible, and can coordinate to metal atoms in a variety of coordination modes such as monodentate, chelating, bidentate bridging, monoatomic bridging, and chelating bridging (Scheme 1). ${ }^{7}$ Bis-Schiff bases

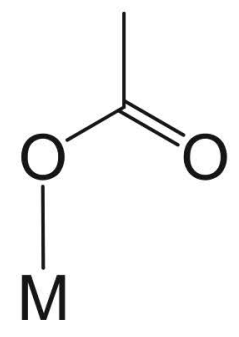

Monodentate $\mu_{1}-\eta^{1}: \eta^{0}$

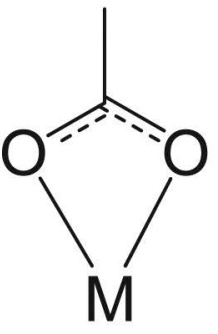

Chelating $\mu_{1}-\eta^{1}: \eta^{1}$
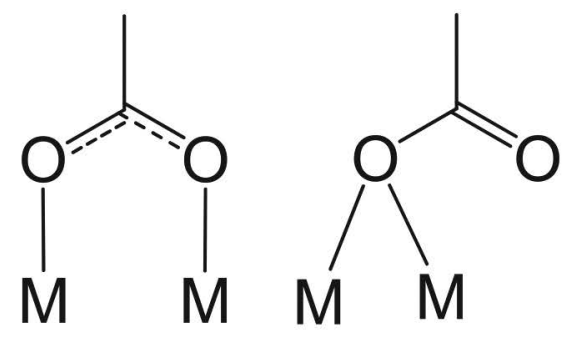

Bidentate bridging Monoatomic bridging $\mu_{2}-\eta^{1}: \eta^{1}$

$$
\mu_{2}-\eta^{2}: \eta^{0}
$$

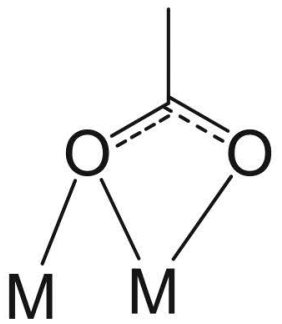

Chelating bridging $\mu_{2}-\eta^{2}: \eta^{1}$

Scheme 1. Various coordination modes of acetate anion 
derived from salicylaldehyde and its derivatives with various diamines usually coordinate to metal atoms through NNOO donor atoms, ${ }^{8}$ thus, it is possible for the introduction of bridging groups. It was reported that Schiff bases bearing electron-withdrawing groups can improve their antimicrobial activities. ${ }^{9}$ Rai and co-workers reported a series of fluoro, chloro, bromo, and iodo-substituted compounds, and found that they have significant antimicrobial activities. ${ }^{10}$ A number of metal complexes have been reported with the bis-Schiff base $N, N^{\prime}$-bis(5-chloro-2-hydroxybenzylidene)-1,3-propanediamine $\left(\mathrm{H}_{2} \mathrm{~L} ; \quad\right.$ Scheme 2). ${ }^{11}$ As a continuation of work on the exploration of new antimicrobial agents, in this paper, a new trinuclear nickel complex was obtained.

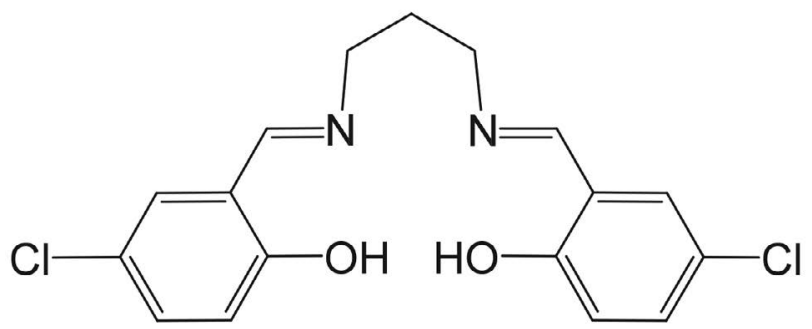

Scheme 2. $\mathrm{H}_{2} \mathrm{~L}$

\section{Experimental}

\section{1. General Methods and Materials}

5-Chlorosalicylaldehyde and 1,3-propanediamine with AR grade were purchased from Sigma-Aldrich. All other chemicals (reagent grade) used were commercially available. Elemental analyses for $\mathrm{C}, \mathrm{H}$ and $\mathrm{N}$ were performed on a Perkin-Elmer 240C elemental analyzer. IR spectra were recorded on a Nicolet AVATAR 360 spectrometer as $\mathrm{KBr}$ pellets in the $4000-400 \mathrm{~cm}^{-1}$ region. ${ }^{1} \mathrm{H}$ NMR and ${ }^{13} \mathrm{C}$ NMR spectra were recorded on a Bruker Avance 300 spectrometer operating at $300 \mathrm{MHz}$ for ${ }^{1} \mathrm{H}$ NMR and $75.5 \mathrm{MHz}$ for ${ }^{13} \mathrm{C}$ NMR. Molar conductivity value was measured with a Shanghai DDS-11A conductometer.

\section{2. Synthesis of $\mathrm{H}_{2} \mathrm{~L}$}

5-Chlorosalicylaldehyde ( $2.0 \mathrm{mmol}, 0.31 \mathrm{~g})$ was dissolved in methanol $(20 \mathrm{~mL})$, to which a methanol solution $(10 \mathrm{~mL})$ of 1,3 -propanediamine $(1.0 \mathrm{mmol}, 0.074 \mathrm{~g})$ was added dropwise with stirring at room temperature. The mixture was stirred at room temperature for $30 \mathrm{~min}$, and most of the solvent was removed by distillation. The yellow crystalline product was obtained by filtration. Yield: $93 \%$ $(0.33 \mathrm{~g})$. IR data $\left(\mathrm{cm}^{-1}, \mathrm{KBr}\right): 3353 \mathrm{w}, 1645 \mathrm{~s}, 1585 \mathrm{~s}, 1487 \mathrm{~s}$, $1382 \mathrm{w}, 1329 \mathrm{w}, 1258 \mathrm{~s}, 1213 \mathrm{~m}, 1127 \mathrm{w}, 1033 \mathrm{~m}, 985 \mathrm{w}, 865 \mathrm{~m}$, $831 \mathrm{~m}, 772 \mathrm{~m} .{ }^{1} \mathrm{H}$ NMR $(300 \mathrm{MHz}, \mathrm{DMSO}) \delta 12.33(\mathrm{~s}, 2 \mathrm{H}$, $\mathrm{OH}), 8.54(\mathrm{~s}, 2 \mathrm{H}, \mathrm{CH}=\mathrm{N}), 7.58(\mathrm{~s}, 1 \mathrm{H}, \operatorname{Ar} H), 7.37(\mathrm{~d}, 1 \mathrm{H}$,
$\operatorname{ArH}), 6.92(\mathrm{~d}, 1 \mathrm{H}, \operatorname{Ar} H), 3.73\left(\mathrm{t}, 4 \mathrm{H}, \mathrm{CH}_{2}\right), 1.99(\mathrm{~m}, 2 \mathrm{H}$, $\left.\mathrm{CH}_{2}\right) .{ }^{13} \mathrm{C}$ NMR $(75 \mathrm{MHz}, \mathrm{DMSO}) \delta 158.77,156.32$, $134.57,131.26,124.81,121.05,117.73,61.78,32.50$. Elemental analysis found: C, 58.32; $\mathrm{H}, 4.67 ; \mathrm{N}, 7.91 \%$, $\mathrm{C}_{17} \mathrm{H}_{16} \mathrm{Cl}_{2} \mathrm{~N}_{2} \mathrm{O}_{2}$ calcd: C, 58.13; H, 4.59; N, 7.98\%.

\section{3. Synthesis of the Complex}

$\mathrm{H}_{2} \mathrm{~L}(0.2 \mathrm{mmol}, 0.70 \mathrm{~g})$ was dissolved in methanol $(20 \mathrm{~mL})$, to which a methanolic solution $(20 \mathrm{~mL})$ of nickel acetate tetrahydrate $(0.3 \mathrm{mmol}, 0.75 \mathrm{~g})$ was added with stirring. The mixture was stirred at room temperature for $30 \mathrm{~min}$ to give a green solution, which was kept still to slow evaporate of the solvents. Green block-like single-crystals suitable for X-ray diffraction were formed. Yield: $45 \%$ $(0.16 \mathrm{~g})$. IR data $\left(\mathrm{cm}^{-1}, \mathrm{KBr}\right): 3451,2910,2862,1637,1580$, 1464, 1416, 1385, 1306, 1164, 1075, 948, 859, 712, 549, 517, 465. Elemental analysis found: C, 43.77; H, 3.98; N, 5.27\%, $\mathrm{C}_{38} \mathrm{H}_{40} \mathrm{Cl}_{4} \mathrm{~N}_{4} \mathrm{Ni}_{3} \mathrm{O}_{11}$ calcd: C, $43.61 ; \mathrm{H}, 3.85 ; \mathrm{N}, 5.35 \%$.

\section{4. X-ray Crystallography}

$\mathrm{X}$-ray diffraction was carried out at a Bruker SMART 1000 CCD area diffractometer equipped with MoKa radiation $(\lambda=0.71073 \AA)$. The collected data were collected with SMART and reduced with SAINT, ${ }^{12}$ and multi-scan absorption correction was performed using SADABS. ${ }^{13}$ The structure of the complex was solved by direct method, and refined against $F^{2}$ by full-matrix least-squares method using SHELXTL. ${ }^{14}$ All of the non-hydrogen atoms were refined anisotropically. The H5A and $\mathrm{H} 5 \mathrm{~B}$ atoms attached to $\mathrm{O} 5$ was located in a difference Fourier map and refined

Table 1. Crystallographic information for the complex

\begin{tabular}{ll}
\hline Parameter & Value \\
\hline Formula & $\mathrm{C}_{38} \mathrm{H}_{40} \mathrm{Cl}_{4} \mathrm{~N}_{4} \mathrm{Ni}_{3} \mathrm{O}_{11}$ \\
$\mathrm{Fw}$ & 1046.67 \\
$T, \mathrm{~K}$ & $298(2)$ \\
Crystal system & Monoclinic \\
Space group & $P 2_{1} / c$ \\
$a, \AA$ & $11.049(2)$ \\
$b, \AA$ & $13.148(2)$ \\
$c, \AA$ & $14.988(2)$ \\
b, & $90.971(1)$ \\
$V, \AA{ }^{3}$ & $2177.0(6)$ \\
$Z$ & 2 \\
$D_{c}$, g cm & \\
$F(000)$ & 1.597 \\
$M^{-3}$ & 1072 \\
Observed reflections $\left[I^{3} 2 \mathrm{~s}(I)\right]$ & 11692 \\
Data/restraints/parameters & 4052 \\
Goodness-of-fit on $F^{2}$ & $2008 / 3 / 284$ \\
$R_{1}, w R_{2}\left[I^{3} 2 \mathrm{~s}(I)\right]^{\mathrm{a}}$ & 1.049 \\
$R_{1}, w R_{2}(\text { all data })^{\mathrm{a}}$ & $0.0642,0.1684$ \\
\hline${ }^{\mathrm{a}} R_{1}=\mathrm{a} \| F o|-| F c|| / \mathrm{a}|F o|, w R_{2}=\left[\mathrm{a} w\left(F o^{2}-F c^{2}\right)^{2} / \mathrm{a} w\left(F o^{2}\right)^{2}\right]^{1 / 2}, w=\left[\sigma^{2}(F o)^{2}\right.$ \\
$\left.+\left(0.091\left(F o^{2}+2 F c^{2}\right) / 3\right)^{2}+0.5732\left(F o^{2}+2 F c^{2}\right) / 3\right]^{-1}$.
\end{tabular}


isotropically, with $\mathrm{O}-\mathrm{H}$ and $\mathrm{H} \cdots \mathrm{H}$ distances restrained to $0.85(1)$ and $1.37(2) \AA$, respectively. The remaining $\mathrm{H}$ atoms were placed in geometrically ideal positions and constrained to ride on their parent atoms. The $\mathrm{O} 6$ atom is disordered and its hydrogen atoms cannot be added reasonably. The crystallographic data for the complex are summarized in Table 1. Selected bond lengths and angles are given in Table 2.

Table 2. Selected bond lengths $(\AA)$ and angles $\left(^{\circ}\right)$ for the complexes with estimated standard deviations (e.s.d.s) in parentheses

\begin{tabular}{lllr}
\hline Ni1-O1 & $1.985(5)$ & Ni1-O2 & $2.018(4)$ \\
Ni1-N1 & $2.009(5)$ & Ni1-N2 & $2.000(6)$ \\
Ni1-O3 & $2.051(6)$ & Ni1-O5 & $2.248(8)$ \\
Ni2-O2 & $2.092(5)$ & Ni2-O1 & $2.117(4)$ \\
Ni2-O4 & $2.121(7)$ & & \\
O1-Ni1-N2 & $170.4(2)$ & O1-Ni1-N1 & $91.2(2)$ \\
N2-Ni1-N1 & $96.1(2)$ & O1-Ni1-O2 & $83.13(18)$ \\
N2-Ni1-O2 & $89.0(2)$ & N1-Ni1-O2 & $172.0(2)$ \\
O1-Ni1-O3 & $92.2(3)$ & N2-Ni1-O3 & $94.0(2)$ \\
N1-Ni1-O3 & $90.3(2)$ & O2-Ni1-O3 & $95.5(2)$ \\
O1-Ni1-O5 & $82.8(3)$ & N2-Ni1-O5 & $91.5(3)$ \\
N1-Ni1-O5 & $85.0(3)$ & O2-Ni1-O5 & $88.7(3)$ \\
O3-Ni1-O5 & $173.1(2)$ & O2-Ni2-O1A & $101.73(18)$ \\
O2-Ni2-O1 & $78.27(17)$ & O2-Ni2-O4A & $92.0(2)$ \\
O1-Ni2-O4A & $90.4(2)$ & O2-Ni2-O4 & $88.0(2)$ \\
O1-Ni2-O4 & $89.6(2)$ & & \\
\hline
\end{tabular}

Symmetry code for A: $1-x,-y,-z$.

\section{5. Antimicrobial Assay}

The antibacterial activity of the compounds was tested against Bacillus subtilis, Staphylococcus aureus, Escherichia coli, and Pseudomonas aeruginosa using LB medium. The antifungal activities of the compounds were tested against Candida albicans and Aspergillus niger using RPMI- 1640 medium. The $\mathrm{IC}_{50}$ (half inhibitory concentration) of the test compounds were determined by a colorimetric method using the dye MTT (3-(4,5-di-methylth-iazol-2-yl)-2,5-diphenyltetrazolium bromide). A stock solution of the synthesized compound (1000 $\mu \mathrm{g}$ $\mathrm{mL}^{-1}$ ) in DMSO was prepared and graded quantities of the test compounds were incorporated in specified quantity of sterilized liquid LB medium. Suspension of the microorganism was prepared and applied to 96-well assay plate with serially diluted compounds to be tested. $10 \mu \mathrm{L}$ of tested samples at pre-set concentrations were added to wells with penicillin $\mathrm{G}$ as a positive reference, the solvent control (5\% DMSO) in medium and incubated at $37^{\circ} \mathrm{C}$ for 24 h. After $24 \mathrm{~h}$ exposure, $10 \mu \mathrm{L}$ of PBS (phosphate buffered saline $0.01 \mathrm{~mol} \mathrm{~L}^{-1}, \mathrm{pH}=7.4$ ) containing $4 \mathrm{mg} \mathrm{mL}^{-1}$ of MTT was added to each well. After $4 \mathrm{~h}$, the medium was replaced by $150 \mu \mathrm{L}$ DMSO to dissolve the purple formazan crystals produced. The absorbance at $492 \mathrm{~nm}$ of each well was measured with an ELISA plate reader. The $\mathrm{IC}_{50}$ value was defined as the concentration at which $50 \%$ of the bacterial strain could survive.

\section{Results and Discussion}

The Schiff base ligand $\mathrm{H}_{2} \mathrm{~L}$ was readily prepared by the condensation reaction of 5-chlorosalicylaldehyde with 1,3-propanediamine in 2:1 molar ratio. Recently, two mononuclear nickel complexes were prepared in a 1:1 molar ratio of nickel acetate and $\mathrm{H}_{2} \mathrm{~L}$ under reflux in methanol. ${ }^{15}$ And also an acetate and phenolate bridged trinuclear nickel complex was prepared by nickel acetate with $\mathrm{H}_{2} \mathrm{~L}$ under solvothermal condition. ${ }^{16}$ Interestingly, the present complex was prepared by the reaction of the Schiff base ligand with nickel acetate in a 2:3 molar ratio under ambient condition. Crystals of the complex are stable in air at room temperature, soluble in DMF, DMSO, $\mathrm{MeOH}, \mathrm{EtOH}$ and $\mathrm{MeCN}$, insoluble in water. The elemental analyses of the complex agree well with the component determined by $\mathrm{X}$-ray analysis. The molar conductivity of the complex measured in DMSO/water at concentration of $10^{-3} \mathrm{~mol} \mathrm{~L}^{-1}$ is $25 \Omega^{-1} \mathrm{~cm}^{2} \mathrm{~mol}^{-1}$, indicating the non-electrolytic nature of the complex in solution. ${ }^{17}$

\section{1. Crystal Structure Description of the Complex}

The molecular structure of the complex is shown in Fig. 1 . The asymmetric unit of the compound contains half of a trinuclear complex. The molecule of the complex possesses crystallographic inversion center symmetry, with the inversion center located at the site of Ni2 atom. There are three bridges across the $\mathrm{Ni}$... Ni atom pairs, involving two phenolate $\mathrm{O}$ atoms of a Schiff base ligand, and an $\mathrm{O}-\mathrm{C}-\mathrm{O}$ moiety of a $\mu_{2}-\eta^{1}: \eta^{1}-\mathrm{OAc}$ group. The acetate bridges linking the central and terminal nickel atoms are mutually trans. The trinuclear nickel complex molecule consists of two NiL units connected to each other by a completely encapsulated third metal atom, Ni2. The adja-

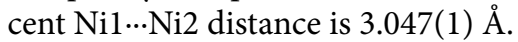

The cage of Ni2 is formed by phenolate bridges, O1 and $\mathrm{O} 2$, from the Schiff base ligands, and by two $\mathrm{O}$ atoms from two $\mu_{2}-\eta^{1}: \eta^{1}$-OAc ligands that furthermore connect the central metal with the two outer metal atoms resulting in an octahedral environment. The coordination around $\mathrm{Ni} 2$ atom displays only slight distortion. The bond distances $\mathrm{Ni}-\mathrm{O}$ are relatively similar and range from $1.985(5)$ to 2.121(7) $\AA$. The greatest deviation of the bond angles from those expected for an ideal octahedral geometry is found for $\mathrm{O} 1-\mathrm{Ni} 2-\mathrm{O} 2$ with $78.3(2)^{\circ}$, and $\mathrm{O} 1-\mathrm{Ni} 2-\mathrm{O} 2 \mathrm{~A}$ with $101.7(2)^{\circ}$. The remaining bond angles are close to the ideal values for the octahedral coordination.

The coordination around the inversion-related terminal $\mathrm{Ni}$ atoms is also octahedral, with two imino $\mathrm{N}$ and two phenolate $\mathrm{O}$ atoms from a Schiff base ligand defining 
the equatorial plane, and with two $\mathrm{O}$ atoms respectively from a methanol and a $\mu_{2}-\eta^{1}: \eta^{1}$-OAc ligands occupying the axial positions. The coordination around the terminal metal atoms also displays slight distortion. The greatest deviation of the bond angles from those expected for an ideal octahedral geometry is $\mathrm{O} 1-\mathrm{Ni1}-\mathrm{O} 2\left(81.9(2)^{\circ}\right)$, which is

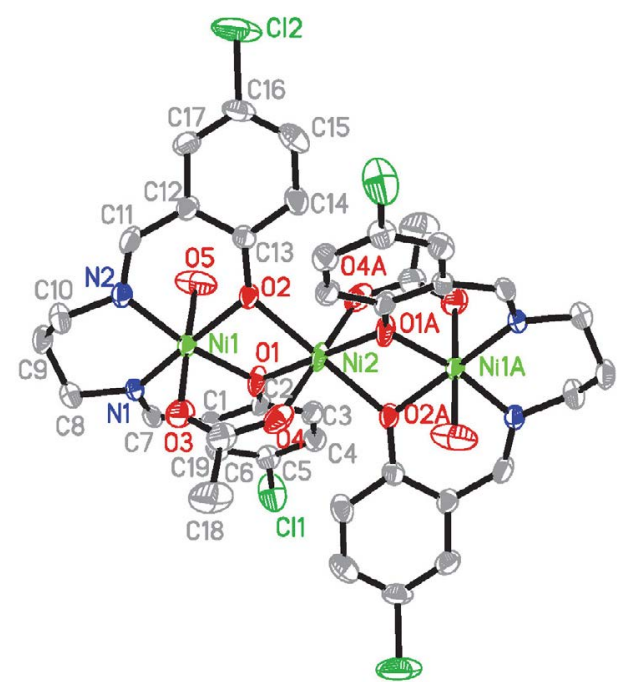

Fig. 1. Molecular structure of the complex. Displacement ellipsoids are drawn at the $30 \%$ probability level and $\mathrm{H}$ atoms are omitted for clarity. Atoms labeled with the suffix A or unlabeled are related to the symmetry position $1-x,-y,-z$.

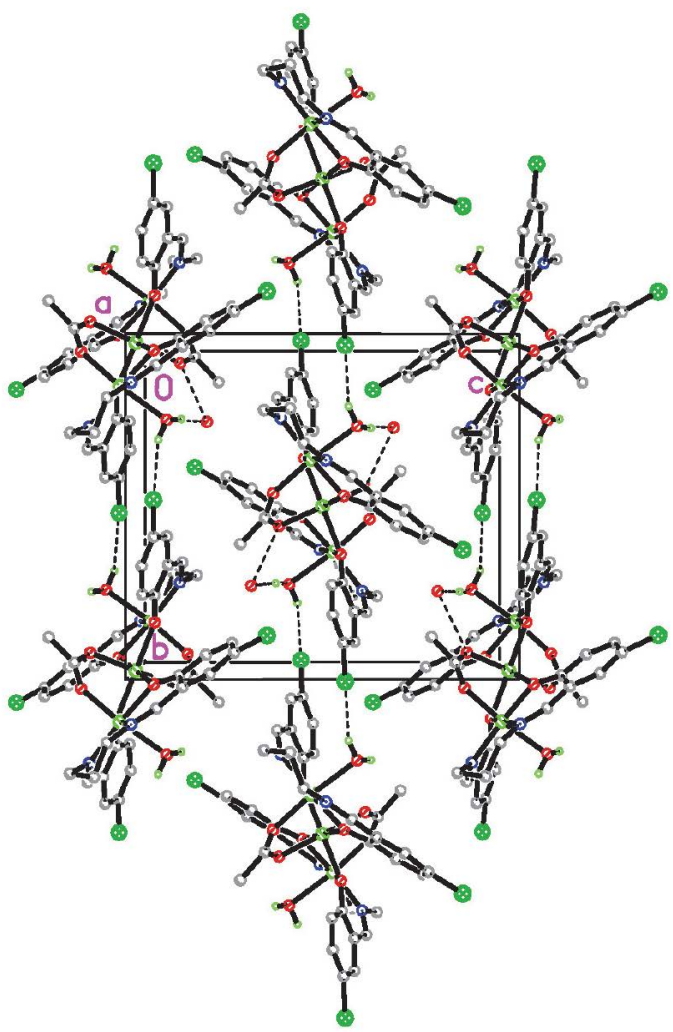

Fig. 2. Molecular packing diagram of the complex, viewed along the $a$ axis. Hydrogen bonds are drawn as dashed lines. caused by the strain created by the four-membered chelate ring $\mathrm{Ni} 1-\mathrm{O} 1-\mathrm{Ni} 2-\mathrm{O} 2$.

The NiL units in the complex are butterfly-shaped, with the dihedral angles formed by the two benzene rings of the Schiff base ligands of 53.2(5) ${ }^{\circ}$. In the crystal structure of the complex, the water hydrate molecules are linked to the nickel complex molecules through $\mathrm{O} 5-\mathrm{H} 5 \mathrm{~A} \cdots \mathrm{O} 66^{\mathrm{i}}$, $\mathrm{O} 5-\mathrm{H} 5 \mathrm{~B} \cdots \mathrm{Cl} 2^{\mathrm{ii}}$ and $\mathrm{C} 18-\mathrm{H} 18 \mathrm{~B} \cdots \mathrm{O} 6^{\mathrm{iii}}$ hydrogen bonds $\left[\mathrm{O} 5-\mathrm{H} 5 \mathrm{~A}=0.86 \AA\right.$, $\mathrm{H} 5 \mathrm{~A} \cdots \mathrm{O}^{\mathrm{i}}=1.66 \AA$, O5 $\cdots \mathrm{O}^{\mathrm{i}}=$ $2.518(5) \AA$, O5-H5A $\cdots \mathrm{O}^{\mathrm{i}}=173^{\circ}$; O5-H5B $=0.85 \AA$, $\mathrm{H} 5 \mathrm{~B} \cdots \mathrm{Cl} 2^{\mathrm{ii}}=2.48 \AA, \mathrm{O} 5 \cdots \mathrm{Cl} 2^{\mathrm{ii}}=3.251(5) \AA$, O5-H5B $\cdots-$ $\mathrm{Cl}^{\mathrm{ii}}=151^{\circ} ; \mathrm{C} 18-\mathrm{H} 18 \mathrm{~B}=0.96 \AA, \mathrm{H} 18 \mathrm{~B} \cdots \mathrm{O} 6^{\mathrm{iii}}=2.36 \AA$, $\mathrm{C} 18 \cdots \mathrm{O}^{\mathrm{iii}}=3.207(5) \AA, \mathrm{C} 18-\mathrm{H} 18 \mathrm{~B} \cdots \mathrm{O} 6^{\mathrm{iii}}=147^{\circ}$; symmetry codes: i: $x, 1 / 2-y, 1 / 2+z$; ii: $1-x,-y, 1-z$; iii: $1-x, 1 / 2+$ $y, 1 / 2-z]$, forming chains along the $b$ axis (Fig. 2).

\section{2. Infrared Spectra}

The IR spectra of the free Schiff base ligand and the nickel complex provide information about the metal-ligand bonding. The assignments are based on the typical group frequencies. The broad absorptions centered at $3353 \mathrm{~cm}^{-1}$ for $\mathrm{H}_{2} \mathrm{~L}$ and $3451 \mathrm{~cm}^{-1}$ for the complex are generated by the $v(\mathrm{O}-\mathrm{H})$ of the hydroxy groups or methanol molecules. The strong absorption band at $1645 \mathrm{~cm}^{-1}$ for $\mathrm{H}_{2} \mathrm{~L}$ is assigned to the azomethine groups, $v(\mathrm{C}=\mathrm{N})$. The band is shifted to 1637 $\mathrm{cm}^{-1}$ in the spectrum of the complex, what can be attributed to the coordination of the nitrogen atoms of the azomethine groups to the metal atoms. The phenolic $v(\mathrm{Ar}-\mathrm{O})$ for the free ligand exhibits medium band at $1213 \mathrm{~cm}^{-1} .{ }^{18}$ However, in the complex, the band appears at $1164 \mathrm{~cm}^{-1}$. This may be assigned to the skeletal vibrations related to the phenolic oxygen of the Schiff base ligands, and the bands are known to shift to lower frequency when the phenolic oxygen coordinates to metal atoms. ${ }^{19}$ There exhibit typical acetate vibrations $v_{\text {asym }}(\mathrm{OAc})$ at $1580 \mathrm{~cm}^{-1}$ and $v_{\text {sym }}(\mathrm{OAc})$ at $1464 \mathrm{~cm}^{-1} \cdot{ }^{20}$

\section{3. Antibacterial Activity}

The complex and the free Schiff base were screened for antibacterial activity against two Gram $(+)$ bacterial strains (B. subtilis and S. aureus) and two Gram (-) bacterial strains (E. coli and $P$. aeruginosa) by MTT method. The $\mathrm{IC}_{50}$ values of the compounds against four bacteria are listed in Table 3. Penicillin $G$ was used as the standard drug. The Schiff base $\mathrm{H}_{2} \mathrm{~L}$ showed medium activity against the bacteria $B$. subtilis, S. aureus, and E. coli, while no activity against $P$. aeruginosa. The complex has strong activity against $B$. subtilis, medium activity against $S$. aureus, while no activity against the other two bacteria. From the results, it is difficult to give a definite conclusion about which one is good for the antibacterial activities of the free Schiff base and the complex. For example, the complex has stronger activities against B. subtilis and $S$. aureus than the Schiff base. However, as for E. coli, the Schiff base has stronger activity than the complex. The particular interest is that 
Table 3. $\mathrm{IC}_{50}$ values $\left(\mu \mathrm{g} \mathrm{mL}^{-1}\right)$ of the tested material

\begin{tabular}{lcccccc}
\hline Tested material & B. subtilis & S. aureus & E. coli & P. aeruginosa & C. albicans & A. niger \\
\hline $\mathrm{H}_{2} \mathrm{~L}$ & 15.50 & 29.11 & 12.35 & $>50$ & $>50$ & $>50$ \\
Complex & 2.16 & 13.33 & $>50$ & $>50$ & 17.72 & $>50$ \\
Penicillin G & 2.38 & 0.71 & 18.23 & 16.31 & $>50$ & $>50$ \\
Ketoconazole & $>50$ & $>50$ & $>50$ & $>50$ & 2.45 & 9.97 \\
\hline
\end{tabular}

the complex showed the most effective activity against $B$. subtilis, which is even more effective than penicillin G.

The antifungal activities of the complex and the free Schiff base were also evaluated against two fungal strains (C. albicans and A. niger) by MTT method. Ketoconazole was used as a reference drug. It is interesting that the complex has effective activity against $C$. albicans, with $\mathrm{IC}_{50}$ value of $17.72 \mu \mathrm{g} \mathrm{mL} L^{-1}$.

\section{Conclusion}

In summary, a new linear trinuclear Schiff base nickel(II) complex derived from $N, N^{\prime}$-bis(5-chloro-2-hydroxybenzylidene)-1,3-propanediamine was presented. Structure of the complex was confirmed by single-crystal X-ray determination. The $\mathrm{Ni}$ atoms are in octahedral coordination. The complex has interesting antibacterial activities against $B$. subtilis and $S$. aureus, and antifungal activity against C. albicans.

\section{Supplementary Material}

CCDC-1507164 contain the crystallographic data for the complex. The data can be obtained at https://www. ccdc.cam.ac.uk or from the Cambridge Crystallographic Data Centre (CCDC), 12 Union Road, Cambridge CB2 1EZ, UK; fax: +44(0)1223-336033 or e-mail: deposit@ ccdc.cam.ac.uk.

\section{Acknowledgments}

This work was financially supported by K.C. Wong Magna Fund in Ningbo University, Ningbo natural science fund (Project No. 201701HJ-B01019), State Key Laboratory Development Fund of Structural Chemistry and Ningbo Education Research Project (Project No. 2017YZD001).

\section{References}

1. (a) P. J. Low, Coord. Chem. Rev. 2013, 257, 1507-1532;

DOI:10.1016/j.ccr.2012.08.008

(b) R. T. Acha, E. L. Gavey, J. Wang, J. M. Rawson, M. Pilking- ton, Polyhedron 2014, 76, 122-127;

DOI:10.1016/j.poly.2014.04.001

(c) D.-L. Peng, N. Sun, Acta Chim. Slov. 2018, 65, 895-901; DOI:10.17344/acsi.2018.4543

(d) X. W. Zhu, Russ. J. Coord. Chem. 2018, 44, 335-339;

(e) H. Y. Qian, X. W. Zhu, Russ. J. Coord. Chem. 2018, 44, 32-38. DOI:10.3103/S1068367418040213

2. A. Bienka, R. Kruszynski, D. Bienko, Polyhedron 2014, 75, 1-8. DOI:10.1016/j.poly.2014.02.045

3. (a) U. Kumar, J. Thomas, N. Thirupathi, Inorg. Chem. 2010, 49, 62-72; DOI:10.1021/ic901100z

(b) R. Biswas, S. Mukherjee, P. Kar, A. Ghosh, Inorg. Chem. 2012, 51, 8150-8160. DOI:10.1021/ic300547w

4. (a) C. Biswas, M. G. B. Drew, E. Ruiz, M. Estrader, C. Diaz, A. Ghosh, Dalton Trans. 2010, 39, 7474-7484;

DOI:10.1039/c0dt00331j

(b) B. Cristovao, J. Klak, B. Miroslaw, Polyhedron 2012, 43, 47-54. DOI:10.1016/j.poly.2012.05.045

5. (a) F. Cimpoesu, F. Dahan, S. Ladeira, M. Ferbinteanu, J.-P. Costes, Inorg. Chem. 2012, 51, 11279-11293;

DOI:10.1021/ic3001784

(b) M. L. Mejia, K. Agapiou, X. P. Yang, B. J. Holliday, J. Am. Chem. Soc. 2009, 131, 18196-18199.

DOI:10.1021/ja906773g

6. (a) H.-H. Li, Z.-L. You, C.-L. Zhang, M. Yang, L.-N. Gao, L. Wang, Inorg. Chem. Commun. 2013, 29, 118-122;

DOI:10.1016/j.inoche.2012.12.023

(b) Z.-L. You, D.-M. Xian, M. Zhang, CrystEngComm 2012, 14, 7133-7137; DOI:10.1039/c2ce25662b

(c) X.-S. Zhou, X.-S. Cheng, Y.-H. Li, F.-Y. Tian, Z.-L. You, Chinese J. Inorg. Chem. 2013, 29, 397-402;

(d) H.-H. Li, X.-X. Zhou, Z.-L. You, Chinese J. Inorg. Chem. 2013, 29, 649-653;

(e) Y.-J. Ren, J.-L. Zhu, L.-X. Zhang, Y.-X. Xu, S.-S. Qian, Acta Chim. Slov. 2017, 64, 825-831.

7. (a) X.-S. Tai, W.-H. Zhao, F.-H. Li, Chinese J. Inorg. Chem. 2013, 29, 1328-1332;

(b) M. M. Kamel, H. I. Ali, M. M. Anwar, N. A. Mohamed, A. M. Soliman, Eur. J. Med. Chem. 2010, 45, 572-580;

DOI:10.1016/j.ejmech.2009.10.044

(c) S. M. Sondhi, S. Arya, R. Rani, N. Kumar, P. Roy, Med. Chem. Res. 2012, 21, 3620-3628.

DOI:10.1007/s00044-011-9899-3

8. (a) M. S. Alam, J.-H. Choi, D.-U. Lee, Bioorg. Med. Chem. 2012, 20, 4103-4108;

DOI:10.1016/j.bmc.2012.04.058

(b) D. Sunil, A. M. Isloor, P. Shetty, B. Chandrakantha, K. Sat- 
yamoorthy, Med. Chem. Res. 2011, 20, 1024-1032; DOI:10.1007/s00044-010-9433-Z

(c) A. Iqbal, H. L. Siddiqui, C. M. Ashraf, M. H. Bukhari, C. M. Akram, Chem. Pharm. Bull. 2007, 55, 1070-1072;

DOI:10.1248/cpb.55.1070

(d) M. B. Ferrari, S. Capacchi, G. Reffo, G. Pelosi, P. Tarasconi, R. Albertini, S. Pinelli, P. Lunghi, J. Inorg. Biochem. 2000, 81, 89-97. DOI:10.1016/S0162-0134(00)00087-8

9. (a) L. Shi, H.-M. Ge, S.-H. Tan, H.-Q. Li, Y.-C. Song, H.-L. Zhu, R.-X. Tan, Eur. J. Med. Chem. 2007, 42, 558-564;

DOI:10.1016/j.ejmech.2006.11.010

(b) M. Zhang, D.-M. Xian, H.-H. Li, J.-C. Zhang, Z.-L. You, Aust. J. Chem. 2012, 65, 343-350. DOI:10.1071/CH11424

10. (a) N. P. Rai, V. K. Narayanaswamy, T. Govender, B. K. Manuprasad, S. Shashikanth, P. N. Arunachalam, Eur. J. Med. Chem. 2010, 45, 2677-2682;

DOI:10.1016/j.ejmech.2010.02.021

(b) N. P. Rai, V. K. Narayanaswamy, S. Shashikanth, P. N. Arunachalam, Eur. J. Med. Chem. 2009, 44, 4522-4527;

(c) J. Meletiadis, J. F. G. M. Meis, J. W. Mouton, J. P. Donnelly, P. E. Verweij, J. Clin. Microbiol. 2000, 38, 2949-2954.

11. (a) L. W. Xue, Y. J. Han, G. Q. Zhao, Y. X. Feng, Russ. J. Coord. Chem. 2012, 38, 24-28; DOI:10.1134/S1070328411120104

(b) M. Maiti, D. Sadhukhan, S. Thakurta, S. Roy, G. Pilet, R. J. Butcher, A. Nonat, L. J. Charbonniere, S. Mitra, Inorg. Chem. 2012, 51, 12176-12187; DOI:10.1021/ic3012958 (c) F. Pan, Z.-M. Wang, S. Gao, Inorg. Chem. 2007, 46, 1022110228; DOI:10.1021/ic701387z

(d) G. Bhargavi, M. V. Rajasekharan, J.-P. Costes, J.-P. Tuchagues, Dalton Trans. 2013, 42, 8113-8123; DOI:10.1039/c3dt31966k

(e) J. H. Yoon, D. W. Ryu, H. C. Kim, S. W. Yoon, B. J. Suh, C. S. Hong, Chem. Eur. J. 2009, 15, 3661-3665.

DOI:10.1002/chem.200900250

12. Bruker, SMART and SAINT. Bruker AXS Inc, Madison, 2002.

13. G. M. Sheldrick, SADABS. University of Göttingen, Germany, 1996.

14. G. M. Sheldrick, SHELXTL V5.1, Software Reference Manual, Bruker AXS Inc, Madison, 1997.

15. A. Elmali, C. T. Zeyrek, Y. Elerman, T. N. Durlu, J. Chem. Crystallogr. 2000, 30, 167-171.

DOI:10.1023/A:1009526913565

16. Z.-L. You, M. Zhang, D.-M. Xian, Dalton Trans. 2012, 41, 2515-2524. DOI:10.1039/c1dt11566a

17. W. J. Geary, Coord. Chem. Rev. 1971, 7, 81-122. DOI:10.1016/S0010-8545(00)80009-0

18. G. C. Percy, D. A. Thornton, J. Inorg. Nucl. Chem. 1972, 34, 3357-3362. DOI:10.1016/0022-1902(72)80230-6

19. C. Fukuhara, E. Asato, T. Shimoji, K. Katsura, M. Mori, K. Matsumoto, S. Ooi, J. Chem. Soc. Dalton Trans. 1987, 13051311.

20. B.-H. Ye, X.-Y. Li, I. D. Williams, X.-M. Chen, Inorg. Chem. 2002, 41, 6426-6431. DOI:10.1021/ic025806+

\section{Povzetek}

Sintetizirali smo nov linearni trijedrni nikljev(II) kompleks s Schiffovo bazo, $\left[\mathrm{Ni}\left\{\mathrm{NiL}\left(\mu_{2}-\eta^{1}: \eta^{1}-\mathrm{OAc}\right)\left(\mathrm{OH}_{2}\right)\right\}_{2}\right] \cdot \mathrm{H}_{2} \mathrm{O}, \mathrm{kjer}$ je L dianionska oblika $N, N^{\prime}$-bis(5-kloro-2-hidroksibenziliden)-1,3-propandiamina $\left(\mathrm{H}_{2} \mathrm{~L}\right)$, in ga okarakterizirali $\mathrm{z}$ elementno analizo, IR spektroskopijo in rentgensko monokristalno analizo. Trije mostovi povezujejo Ni-Ni atomske pare, in sicer preko dveh fenolatnih $\mathrm{O}$ atomov Schiffove baze in $\mathrm{O}-\mathrm{C}-\mathrm{O}$ skupine $\mu_{2}-\eta^{1}: \eta^{1}$-OAc liganda. Nikljevi atomi imajo oktaedrično koordinacijo. Acetatna mostova, ki povezujeta sredinski in terminalna nikljeva atoma, sta $\mathrm{v}$ medsebojnem trans položaju. Ni...Ni razdalja je 3.047(1) Å. Kompleksu smo določili antibakterijske (Bacillus subtilis, Staphylococcus aureus, Escherichia coli in Pseudomonas aeruginosa) in antimikotične (Candida albicans in Aspergillus niger) lastnosti $\mathrm{z}$ uporabo MTT (3-(4,5-dimetiltiazol-2-il)-2,5-difeniltetrazolijev bromid) metode. 